\title{
The Crystal Structure of Silver Ethylenediamine Perchlorate
}

\author{
EVA BANG
}

Department I, Inorganic Chemistry, H. C. Ørsted Institute, University of Copenhagen, Universitetsparken 5, DK-2100 Copenhagen Ø, Denmark

The crystal structure of $\mathrm{Ag}\left(\mathrm{NH}_{2} \mathrm{CH}_{2} \mathrm{CH}_{2} \mathrm{NH}_{2}\right) \mathrm{ClO}_{4}$ has been determined from three-dimensional X-ray data, using $M o K \alpha$ radiation. The crystals are monoclinic, space group $P 21 / c, a=8.834(4), b=$ 9.885(2), $c=9.893(4) \AA, \beta=125.09(2)^{\circ}, Z=4$. The coordination of the silver atom is almost linear $\left(175.8^{\circ}\right)$ with bond distances $\mathrm{Ag}-\mathrm{N} 2.17(1) \AA$. The complex forms infinite chains with a bridging ethylenediamine between the silver atoms.

Equilibrium studies of aqueous silver(I) and ethylenediamine solutions have led to detection of dimeric species $\mathrm{Ag}_{2}\left(\mathrm{NH}_{2} \mathrm{CH}_{2} \mathrm{CH}_{2} \mathrm{NH}_{2}\right)_{2}^{2+}$ and a ring structure has been suggested. ${ }^{1}$ Dimeric silver complexes with ring structures and $\mathrm{Ag}-\mathrm{Ag}$ distances as short as in the silver metal are found in several crystal structures. ${ }^{2,3}$ The structural investigation reported here was suggested by G. Schwarzenbach and led to further investigations of the aqueous system.

\section{EXPERIMENTAL}

The crystals of $\mathrm{Ag}\left(\mathrm{NH}_{2} \mathrm{CH}_{2} \mathrm{CH}_{2} \mathrm{NH}_{2}\right) \mathrm{ClO}_{4}$ were kindly provided by $\mathrm{G}$. Schwarzenbach, Zürich, and were flat needles of rather poor quality. They were assigned to space group $P 2_{1} / c$ through Weissenberg and precession photographs. Intensity data were collected on a Picker FACS-1 diffractometer with graphite-monochromated $\operatorname{MoK} \alpha \quad(\gamma=0.7107 \AA)$ radiation. The measurements were carried out in the $\theta-2 \theta$ mode. The scan rate was $2^{\circ} \mathrm{min}^{-1}$, the scan range $3.6^{\circ}$ and increasing with $2 \theta$. The background counts were made for $20 \mathrm{~s}$ at each end of the scan range.

From the 5238 reflections measured 1985 independent reflections had $I / \sigma(I)>1.0 . \sigma(I)$ is the standard deviation of the intensity calculated from counting statistics. 1669 reflections for which $0<\sin$ $\theta / \lambda<0.66$ were used in the final refinement. The crystal size was $0.14 \times 0.04 \times 0.33 \mathrm{~mm}^{3}$. The large face was $(010)$ with the needle axis as $c$. During the exposure the crystal changed from almost colourless to completely black, but this did not seem to affect the intensity measurements. The cell dimensions were refined from powder diagrams obtained from a Hägg-Guinier camera using $\mathrm{CuK} \alpha$ radiation $(\lambda=1.5405 \AA)$ and $\mathrm{Si}$ as internal standard.

The X-ray system ${ }^{4}$ was used in the crystal structure analyses and the Ortep $\mathrm{II}^{5}$ for the illustrations.

\section{CRYSTAL DATA}

$\mathrm{AgC}_{2} \mathrm{~N}_{2} \mathrm{H}_{8} \mathrm{ClO}_{4}$; Monoclinic, $P 2{ }_{1} / c ; a=8.834(4)$, $b=9.885(2), c=9.893(4), \beta=125.09(2), V=706.85 \AA^{3}$, $D_{m}=2.40, \quad D_{x}=2.51 \mathrm{~g} \mathrm{~cm}^{-3}, \quad Z=4, \mu(\mathrm{MoK} \alpha)=$ $31 \mathrm{~cm}^{-1}$.

\section{SOLUTION OF THE STRUCTURE}

The silver atom was located through the Patterson function. The solution went then straightforward through Fourier methods. No determination of the position of hydrogen atoms has been attempted. The structure was refined isotropically

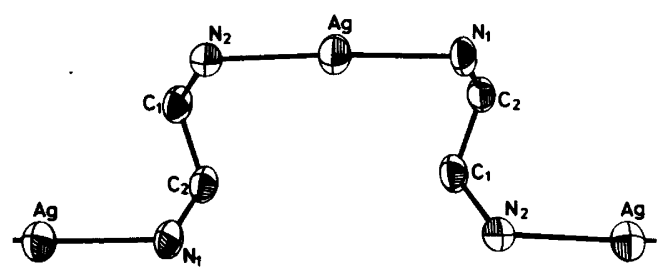

Fig. 1. The Ag complex. Thermal ellipsoids are at $50 \%$ probability. 
Table 1. Fractional atomic coordinates $\left(\times 10^{4}\right)$, anisotropic thermal parameters $\left(\AA^{2} \times 10^{2}\right)$. The anisotropic temperature factor is of the form $\mathrm{T}=\exp \left[-2 \pi^{2}\left(U_{11} h^{2} a^{* 2}+\cdots+2 U_{12} h k a^{*} b^{*}+\cdots\right)\right]$.

\begin{tabular}{llcllllllr}
\hline & $x$ & $y$ & $z$ & $U_{11}(U)$ & $U_{22}$ & $U_{33}$ & \multicolumn{1}{c}{$U_{12}$} & \multicolumn{1}{c}{$U_{13}$} & \multicolumn{1}{c}{$U_{23}$} \\
\hline $\mathrm{Ag}$ & $1929(1)$ & $914(1)$ & $685(1)$ & $5.29(5)$ & $4.64(4)$ & $4.28(4)$ & $-0.50(3)$ & $3.51(4)$ & $-0.40(3)$ \\
$\mathrm{N} 1$ & $2073(11)$ & $3990(8)$ & $3569(10)$ & $5.4(5)$ & $3.8(4)$ & $3.7(4)$ & $0.2(4)$ & $3.2(4)$ & $0.2(3)$ \\
$\mathrm{N} 2$ & $1923(11)$ & $945(8)$ & $2874(10)$ & $4.8(4)$ & $4.4(4)$ & $4.3(4)$ & $-0.9(4)$ & $3.7(4)$ & $-0.6(4)$ \\
$\mathrm{C} 1$ & $3521(13)$ & $1689(10)$ & $4293(11)$ & $4.2(5)$ & $4.2(5)$ & $3.7(5)$ & $0.6(4)$ & $2.9(4)$ & $0.6(4)$ \\
$\mathrm{C} 2$ & $3645(14)$ & $3132(10)$ & $3881(12)$ & $4.4(4)$ & $4.8(5)$ & $4.5(5)$ & $-0.3(4)$ & $3.5(5)$ & $0.1(4)$ \\
& & & & & & & & & \\
$\mathrm{Cl}$ & $7821(3)$ & $1905(2)$ & $3975(2)$ & $3.61(10)$ & $3.53(10)$ & $3.17(10)$ & $-0.04(8)$ & $2.50(9)$ & $-0.06(8)$ \\
$\mathrm{O} 1$ & $6419(11)$ & $909(9)$ & $3014(10)$ & $5.8(2)$ & & & & & \\
$\mathrm{O} 2$ & $9466(12)$ & $1542(9)$ & $4072(10)$ & $6.1(2)$ & & & & & \\
$\mathrm{O} 3$ & $8286(11)$ & $3053(8)$ & $628(10)$ & $5.3(2)$ & & & & & \\
$\mathrm{O} 4$ & $7146(13)$ & $3191(10)$ & $3240(11)$ & $6.6(2)$ & & & & &
\end{tabular}

Table 2. Bond lengths $(\AA)$ and selected distances.

\begin{tabular}{llll}
\hline $\mathrm{Ag}-\mathrm{N} 1$ & $2.171(11)$ & $\mathrm{Cl}-\mathrm{O} 1$ & $1.433(8)$ \\
$\mathrm{Ag}-\mathrm{N} 2$ & $2.170(11)$ & $\mathrm{Cl}-\mathrm{O} 2$ & $1.445(12)$ \\
$\mathrm{N} 1-\mathrm{C} 2$ & $1.500(16)$ & $\mathrm{Cl}-\mathrm{O} 3$ & $1.440(10)$ \\
$\mathrm{N} 2-\mathrm{C} 1$ & $1.492(11)$ & $\mathrm{Cl}-\mathrm{O} 4$ & $1.414(9)$ \\
$\mathrm{C} 1-\mathrm{C} 2$ & $1.504(15)$ & & \\
& & & \\
$\mathrm{N} 1-\mathrm{O} 1$ & $3.198(12)$ & & \\
$\mathrm{N} 1-\mathrm{O} 2$ & $3.310(12)$ & & \\
$\mathrm{N} 1-\mathrm{O} 3$ & $3.054(9)$ & & \\
$\mathrm{N} 2-\mathrm{O} 2$ & $3.069(18)$ & & \\
$\mathrm{N} 2-\mathrm{O} 3$ & $3.274(13)$ & & \\
$\mathrm{N} 2-\mathrm{O} 3$ & $3.374(11)$ & & \\
$\mathrm{N} 2-\mathrm{O} 4$ & $3.217(15)$ & & \\
$\mathrm{Ag}-\mathrm{Ag}$ & $3.377(1)$ & & \\
\hline
\end{tabular}

until $R=0.11$ and then anisotropically for all atoms apart from oxygen. The final $R$ value was 0.07 . Unit weights were used. The atomic parameters are given in Table 1, bond-lengths and angles in Tables 2 and 3. A list of observed and calculated structure factors can be obtained from the author on request.
Table 3. Selected angles $\left({ }^{\circ}\right)$.

\begin{tabular}{llll}
\hline $\mathrm{N} 1-\mathrm{Ag}-\mathrm{N} 2$ & $175.8(3)$ & $\mathrm{O} 1-\mathrm{Cl}-\mathrm{O} 2$ & $109.0(6)$ \\
$\mathrm{Ag}-\mathrm{N} 1-\mathrm{C} 2$ & $112.7(6)$ & $\mathrm{O} 1-\mathrm{Cl}-\mathrm{O} 3$ & $110.3(6)$ \\
$\mathrm{Ag}-\mathrm{N} 2-\mathrm{C} 1$ & $113.7(8)$ & $\mathrm{O} 1-\mathrm{Cl}-\mathrm{O} 4$ & $109.2(5)$ \\
$\mathrm{N} 1-\mathrm{C} 2-\mathrm{C} 1$ & $112.9(11)$ & $\mathrm{O} 2-\mathrm{Cl}-\mathrm{O} 3$ & $108.2(5)$ \\
$\mathrm{N} 2-\mathrm{C} 1-\mathrm{C} 2$ & $112.9(9)$ & $\mathrm{O} 2-\mathrm{Cl}-\mathrm{O} 4$ & $111.6(7)$ \\
& & $\mathrm{O} 3-\mathrm{Cl}-\mathrm{O} 4$ & $108.6(6)$
\end{tabular}

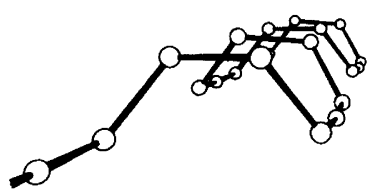

Fig. 2. The chain $\mathrm{Ag}(\mathrm{en})$.

\section{DESCRIPTION OF THE STRUCTURE}

The complex forms infinite chains, Figs. 1 and 2. All $\mathrm{Ag}-\mathrm{N}$ bonds are very nearly parallel to the $c$-axis and the almost linear group $\mathrm{N}-\mathrm{Ag}-\mathrm{N}$ is

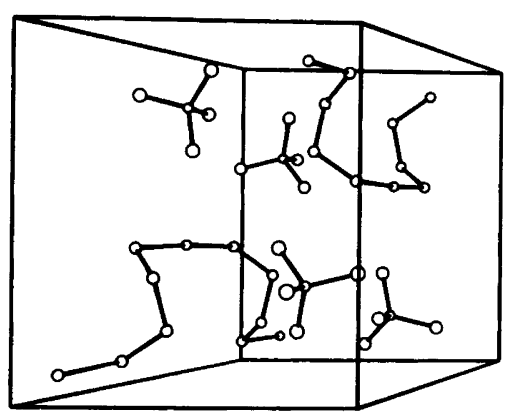

Fig. 3. Stereoscopic view perpendicular to the $a b$ plane. 
connected to the two neighbouring groups through the glide plane, Fig. 3. The carbon atoms are all on the same side of the chain, Fig. 2. The complex possesses a pseudo symmetry plane through the silver atom perpendicular to the $c$-axis. The chlorine atom in the shortest distance from the silver atom lies almost in this plane. The conformation of the ethylenediamine is reasonable, the torsion angle $\mathrm{N}-\mathrm{C}-\mathrm{C}-\mathrm{N}$ being $67(1)^{\circ}$. The $\mathrm{Ag}-\mathrm{N}$ distances are slightly larger than found in diimidazole silver nitrate, ${ }^{2,6} 2.12-2.13$, and in glycinato silver, ${ }^{2}$ $2.11-2.14 \AA$.

The perchlorate ion is not disordered. For each nitrogen atom there is one short distance to the oxygen atoms, which could indicate hydrogen bonds, $3.05-3.09 \AA$. The infinite chains and the perchlorate ions form double layers parallel to the $b c$ plane. The interactions between these layers are very weak. This is consistent with the easy splitting of the crystal along the $c$-axis.

Solution experiments are in progress in this laboratory to investigate if further polymerization takes place in aqueous solution.

\section{REFERENCES}

1. Schwarzenbach, G., Ackermann, H., Maissen, B. and Anderegg, G. Helv. Chim. Acta 35 (1952) 2337.

2. Acland, C. B. and Freeman, H. C. Chem. Commun. (1971) 1016.

3. Baenziger, N. C. and Struss, A. W. Inorg. Chem. 15 (1976) 1807.

4. Stewart, J. M., Kundell, F. A. and Baldwin, J. C. The X-Ray System 1972, Technical Report 92, Computer Science Center, University of Maryland, College Park.

5. Johnson, C. K. Ortep: A Fortran Ellipsoid Plot Program for Crystal Structure Illustrations, Report ORNL-3794, Sec. Rev., Oak Ridge National Laboratory, Oak Ridge 1970.

6. Antti, C.-J. and Lundberg, B. Acta Chem. Scand. 25 (1971) 1758.

Received February 6, 1978. 